\title{
CD4 T-HELPER CELL COUNT IS AN ALTERNATIVE PROMISING MARKER FOR DOSING CYCLOSPORINE IN KIDNEY TRANSPLANT PATIENT
}

\author{
JAAFAR JABER IBRAHEEM AL-TAMIMI'1, QUTAIBA AHMED IBRAHIM AL-KHAMES AGA², \\ HASSAN MOHAMMED ABASS ${ }^{3}$
}

\begin{abstract}
${ }^{1}$ Biopharmaceutics and Clinical Pharmacokinetics from Uppsala University, Sweden, 1985, ${ }^{2}$ Department of Clinical Pharmacy, College of Pharmacy, the University of Baghdad, Iraq, ${ }^{3}$ Clinical Pharmacy, Baghdad Teaching Hospital, Medical City, Baghdad, Iraq

Email: drhaltemimi@dr.com
\end{abstract}

Received: 04 Apr 2016 Revised and Accepted: 22 Jul 2016

\begin{abstract}
Objective: The study was aimed to find out the correlation between cyclosporine blood concentrations and (Clusters of Differentiation 4) CD4 Thelper cell count (percentage) in order to use the latter parameter as an alternative marker for cyclosporine dosing. Besides, the study was also aimed to find out the optimum dosing strategy for Iraqi patients requiring cyclosporine therapy in Iraqi hospitals using TDM approach.

Methods: One hundred and twenty subjects participated in the study. The subjects are involved two groups; group A was 80 patients (53 males and 27 females) using cyclosporine twice daily (Sandimmune ${ }^{\circledR}$ oral solution containing cyclosporine $100 \mathrm{mg} / \mathrm{ml}$ ) and they had kidney transplantation for more than one year. The ages of the patients were 15-45 y (mean $\pm S D=31.962 \pm 8.8207)$; and. Group B included 40 healthy control subjects (24 males and 16 females) with ages of $15-45 \mathrm{y}($ mean $\pm \mathrm{SD}=31.666 \pm 8.1606)$. According to the condition and the need of the patients, they were administered cyclosporine dose range of $1-10 \mathrm{mg} / \mathrm{kg} / \mathrm{d}$. Ten $\mathrm{ml}$ blood samples were withdrawn from each patient after fasting for about $12 \mathrm{~h}$ for monitoring trough/minimum blood concentration (C0) of cyclosporine and for determination of (Clusters of Differentiation 4) CD4 T-helper cells count at $\mathrm{C} 0$. Other $10 \mathrm{ml}$ of blood was then withdrawn after $2 \mathrm{~h}$ of cyclosporine administration to be used for monitoring maximum/peak cyclosporine blood cyclosporine (Cmax) after $2 \mathrm{~h}$ of drug intake (C2) and for determination of (Clusters of Differentiation 4) CD4 T-helper cells count at C2. Five ml of blood samples were withdrawn from each control subject for determination of (Clusters of Differentiation 4) CD4 T-helper
\end{abstract} cells count.

Results: Good correlations were found between cyclosporine dose administered to each patient and the resulted C0 and C2. The majority of patients ( 66 patients $=82.5 \%$ ) had C0 of 150-200 ng/ml and C2 of 700-900 ng/ml, which are within the therapeutic range. The range of cyclosporine doses that produce therapeutic $\mathrm{C} 0$ and $\mathrm{C} 2$ was $4.1-9 \mathrm{mg} / \mathrm{kg} / \mathrm{d}$. The mean total lymphocyte count and percentage decreased significantly in all patients compared to the control subjects $\left(1.26 \pm 0.60\right.$ vs. $\left.1.98 \pm 0.66 \mathrm{e}^{3} / \mathrm{uL}\right)$ and $(19.92 \pm 13.77$ vs. $28.88 \pm 10.22)$, respectively. A similar trend was found for the total lymphocyte count and percentage of patients with cyclosporine $\mathrm{C} 0$, and $\mathrm{C} 2$ within the therapeutic range (66 patients) compared to the control subjects $(1.34 \pm 0.57$ vs. $1.98 \pm 0.66)$ and $(18.98 \pm 10.93$ vs. $28.88 \pm 10.22)$, respectively. Good negative correlations were found between lymphocyte count and percentage versus $\mathrm{C} 0$ for all patients and for patients with $\mathrm{C} 0$ within the therapeutic range. Similarly, good negative correlations were found between lymphocyte count and percentage versus $\mathrm{C} 2$ for all patients and for patients with $\mathrm{C} 2$ within the therapeutic range. The (Clusters of Differentiation 4) CD4 T-helper cell percentage at C0 decreased significantly in all patients and patients with cyclosporine blood concentrations within the therapeutic range (66 patients) compared to the control subjects $(24.33 \pm 10.31$ vs. $35.83 \pm 9.11)$ and $(25.50 \pm 2.44$ vs. $35.83 \pm 9.11$ ), respectively. Similarly, (Clusters of Differentiation 4) CD4 T-helper cell percentage at C2 decreased significantly in all patients and patients with cyclosporine blood concentrations within the therapeutic range compared to the control subjects $(22.60 \pm 9.28$ vs. $35.83 \pm 9.11)$ and (21.50 \pm 2.16 vs. $35.83 \pm 9.11$ ), respectively. The range of (Clusters of Differentiation 4) CD4 T-helper cell percentages at C0 for patients with cyclosporine blood levels above the therapeutic concentrations was 21.65-23.43; for patients with cyclosporine blood levels within the therapeutic concentrations, the range was 23.70-29.00; and for patients with cyclosporine blood levels below the therapeutic concentrations, the range was 29.80-34.60. Good negative correlations were found between (Clusters of Differentiation 4) CD4 T-helper cell percentage and C0 for all patients and for patients with blood concentrations of cyclosporine within the therapeutic range. The (Clusters of Differentiation 4) CD4 T-helper cell percentage range at $\mathrm{C} 2$ for patients with cyclosporine blood levels above the therapeutic concentrations was 13.40-18.20; for patients with cyclosporine blood levels within the therapeutic concentrations, the range was 18.50-22.23; and for patients with cyclosporine blood levels below the therapeutic concentrations, the range was 22.76-24.42. Identically, good negative correlations were found between (Clusters of Differentiation 4) CD4 T-helper cell percentage and C2 for all patients and for patients with blood concentrations of cyclosporine within the therapeutic range. For patients with cyclosporine blood levels above therapeutic concentrations; the minimum percentage of (Clusters of Differentiation 4) CD4 T-helper cell at C2 was 13.40, whereas, the maximum percentage of (Clusters of Differentiation 4) CD4 T-helper cell at C0 was 20.23. For patients with cyclosporine blood levels within therapeutic concentrations; the minimum percentage of (Clusters of Differentiation 4) CD4 T-helper cell at C2 was 18.50, whereas, the maximum percentage of (Clusters of Differentiation 4) CD4 T-helper cell at C0 was 29.00. For patients with cyclosporine blood levels below therapeutic concentrations; the minimum percentage of (Clusters of Differentiation 4) CD4 T-helper cell at C2 was 23.40, whereas, the maximum percentage of (Clusters of Differentiation 4) CD4 T-helper cell at C0 was 34.60.

Conclusion: Good negative (reciprocal) correlations were demonstrated between cyclosporine blood concentrations at C0 and C2 versus The percentage of (Clusters of Differentiation 4) CD4 T-helper cell. Therefore, the percentage of (Clusters of Differentiation 4) CD4 T-helper cell may be used as an alternative or surrogate marker for optimum cyclosporine dosing than the traditional dosing strategy using TDM, since the former approach is direct for reflecting drug safety and efficacy, beside, it is the affordable, fast and simple approach. The range of cyclosporine doses that produce therapeutic C0 and C2 in Iraqi kidney transplant patients was $4.1-9 \mathrm{mg} / \mathrm{kg} / \mathrm{d}$.

Keywords: Cyclosporine, Kidney transplantation, TDM, (Clusters of Differentiation 4) CD4 T-helper cell, Trough blood concentration of cyclosporine (C0), Maximum blood concentration of cyclosporine (C2)

(C) 2016 The Authors. Published by Innovare Academic Sciences Pvt Ltd. This is an open access article under the CC BY license (http://creativecommons. org/licenses/by/4. 0/) DOI: http://dx.doi.org/10.22159/ijpps.2016.v8i9.12030 


\section{INTRODUCTION}

Cyclosporine also called cyclosporine A and Ciclosporin (often shortened to CsA). Cyclosporine is indicated for the prophylaxis of organ rejection in heart, liver and kidney allogeneic transplants. Besides, cyclosporine may also be indicated for patients who were previously treated with other immunosuppressive agents. Although many cells may participate in the process of kidney transplant rejection, only $\mathrm{T}$ lymphocytes seem to be absolutely required $[1,2]$. T-lymphocytes cells express either the CD4 or the CD8 surface glycoprotein but not both $[3,4]$. The main event in both the initiation and coordination of the rejection responses T-cell activation, moderated by interleukin- 2 , a cytokine. Interleukin- 2 is produced by CD4 cells and to a lesser extent by CD8 cells $[5,6]$.

There are so many reasons, which make cyclosporine a distinguished example of drugs, which require drug monitoring, and individualization for optimal therapy to the patients. These reasons include; narrow therapeutic index of the drug (the drug causes irreversible kidney damage when given above therapeutic dose, and on the other extreme cause rejection of transplanted organ when given below therapeutic dose), the existence of number of drug interactions that affect cyclosporine levels, variable inter-and intrapatients pharmacokinetics, in addition to, the differences in the drug pharmacokinetics between formulas and manufacturers [7, 8].

Many studies demonstrated the impact of cyclosporine on reducing CD4-T helper cells, which are responsible for immunosuppression caused by cyclosporine in renal transplant patients [9-12]. However, up to date, there is no published data which show the correlation between cyclosporine dose administered and the resulting trough and maximum concentrations of the drug, in one hand, and the percent of the reduction in CD4-T helper cells, on the other hand. Therefore, the present investigation was aimed to find out the correlation between cyclosporine levels and the percent of the reduction in CD4-T helper cells, since the latter approach is considered as a direct marker, which reflects cyclosporine safety and efficacy. Besides, measuring CD4-T helper cells is the affordable, simple, easy and fast approach. The other objective of the current study was to find out the therapeutic dose range of cyclosporine, which produces therapeutic blood levels in Iraqi kidney transplant patients.

\section{MATERIALS AND METHODS}

\section{Study design}

The study was conducted in TDM Center, Baghdad Teaching Hospital, Medical City/Baghdad/Iraq. Eighty renal transplant patients (53 males and 27 females) who have been using cyclosporine (Sandimmune ${ }^{\circledR}$ oral solution containing cyclosporine
$100 \mathrm{mg} / \mathrm{ml}$ ) for at least one year were involved in the study. These patients were classified as group A. Beside, 40 healthy subjects (24 male and 16 female) were also included in the study as control subjects, and these subjects were classified as group B. All patients and control subjects gave informed consent for participation before the initiation of the study.

\section{Blood sampling from the patients}

After fasting for about $12 \mathrm{~h}$, few minutes before administration of the next cyclosporine dose; $10 \mathrm{ml}$ of blood sample was withdrawn from each patient and transferred immediately to tube containing EDTA to be used for monitoring the trough/minimum concentration ( $\mathrm{C} 0$ ) of cyclosporine, and for determination CD4 T-helper cells count at C0. Other $10 \mathrm{ml}$ of blood was then withdrawn after $2 \mathrm{~h}$ of cyclosporine administration to be used for monitoring cyclosporine after $2 \mathrm{~h}$ (C2) of cyclosporine administration (which represent the peak or maximum level), and for determination CD4 T-helper cells count at C2.

\section{Blood sampling from the control subjects}

Five ml blood was withdrawn from each healthy control subject after fasting for about $12 \mathrm{~h}$ to be used for determination CD4 Thelper cells count.

\section{Determination of cyclosporine blood concentrations in the patients}

Cyclosporine blood concentrations were determined by Abbott AxSYM system. The AxSYM assay is a fluorescence polarization immunoassay (FPIA) in vitro reagent system used for quantitative measurement of cyclosporine in human whole blood as an aid in the management of organ transplantation $[13,14]$.

\section{Determination of CD4 T-helper cells percentage}

The percentage of CD4 T-helper cells was measured by Partec GMBH flow cytometry $[15,16]$.

\section{Statistical analysis of data}

Statistical analysis of the results obtained in this study included; mean \pm standard deviation (SD), analysis of variance (ANOVA) single factor, and correlation coefficient (r). The results of the analysis with $P$ value $<0.05$ were considered significant. Statistical analysis and graphs were carried out by Microsoft Office Excel 2007 software.

\section{RESULTS AND DISCUSSION}

\section{Doses of cyclosporine taken by the patients}

Table 1 shows the number and the percentage of patients versus cyclosporine doses taken by the patients.

Table 1: Cyclosporine doses taken versus number and percentage of patients

\begin{tabular}{lll}
\hline Cyclosporine dose $\mathbf{~ m g} / \mathbf{k g} / \mathbf{d}$ & Number of patients & Percentage of patients \\
\hline $1-2 \mathrm{mg} / \mathrm{kg} / \mathrm{d}$ & 1 & $1.25 \%$ \\
$2.1-3 \mathrm{mg} / \mathrm{kg} / \mathrm{d}$ & 3 & $3.75 \%$ \\
$3.1-4 \mathrm{mg} / \mathrm{kg} / \mathrm{d}$ & 5 & $6.25 \%$ \\
$4.1-5 \mathrm{mg} / \mathrm{kg} / \mathrm{d}$ & 11 & $13.75 \%$ \\
$5.1-6 \mathrm{mg} / \mathrm{kg} / \mathrm{d}$ & 31 & $38.75 \%$ \\
$6.1-7 \mathrm{mg} / \mathrm{kg} / \mathrm{d}$ & 9 & $11.25 \%$ \\
$7.1-8 \mathrm{mg} / \mathrm{kg} / \mathrm{d}$ & 7 & $8.75 \%$ \\
$8.1-9 \mathrm{mg} / \mathrm{kg} / \mathrm{d}$ & 8 & $10 \%$ \\
$9.1-10 \mathrm{mg} / \mathrm{kg} / \mathrm{d}$ & 5 & $6.25 \%$ \\
Total & 80 & $100 \%$ \\
\hline
\end{tabular}

\section{Blood levels of cyclosporine in the patients}

Table 2 shows cyclosporine minima (trough) blood concentrations $(\mathrm{CO})$ and the maximum concentration after $2 \mathrm{~h}$ of drug intake (C2).

For C0; the level was less than $150 \mathrm{ng} / \mathrm{ml}$ in 9 patients (11.25\%), more than $200 \mathrm{ng} / \mathrm{ml}$ in 5 patients $(6.25 \%)$, and within the therapeutic range of $150-200 \mathrm{ng} / \mathrm{ml}$ in 66 patients (82.5\%). C2; the level was less than $700 \mathrm{ng} / \mathrm{ml}$ in 9 patients (11.25\%), more than 900 $\mathrm{ng} / \mathrm{ml}$ in 5 patients $(6.25 \%)$, and within the therapeutic range of $700-900 \mathrm{ng} / \mathrm{ml}$ in 66 patients (82.5\%).

\section{Relationship between cyclosporine dose and concentrations}

Fig. 1 demonstrates the relationship between the doses taken by the patients and C0. Fig. 2 demonstrates the relationship between the doses taken by the patients and C2. In both situations, a good correlation was found between doses taken and the corresponding C0 (r=0.90199, fig. 1), and C2 (r=0.91415, fig. 2). 
Lymphocytes count versus blood levels of cyclosporine for the patients versus the control subjects

Table 3 indicates that the mean total lymphocyte count decreased significantly in all the patients compared to control subjects $\left(1.26 \pm 0.60\right.$ vs. $\left.1.98 \pm 0.66 \mathrm{e}^{3} / \mathrm{uL}\right)$. A similar trend was found for total lymphocyte count in patients with cyclosporine $\mathrm{C} 0$, and $\mathrm{C} 2$ within the therapeutic range (66 patients) compared to control subjects $(1.34 \pm 0.57$ vs. $1.98 \pm 0.66)$.

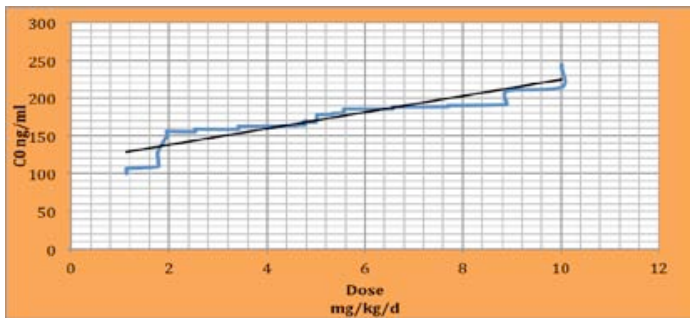

Fig. 1: Relationship between cyclosporine doses and blood trough concentrations (CO)

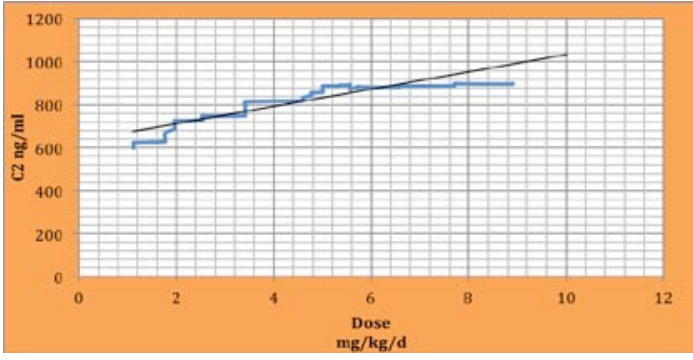

Fig. 2: Relationship between cyclosporine doses and blood concentrations after $2 \mathrm{~h}$ of drug intake (C2)

The correlation between lymphocyte count and $\mathrm{C} 0$ for all patients and for patients with $\mathrm{C} 0$ within therapeutic range is presented in fig. $4 \mathrm{~A}$ and $4 \mathrm{~B}$, respectively. In both situations, the good negative correlation was found between lymphocyte count and $\mathrm{C} 0$ with $\mathrm{r}=0.93295$ (fig. 3.25A), and r=0.97361(fig. 3.25B)

Table 2: Sampling time and blood levels of cyclosporine versus number of patients. Total number of patients=80

\begin{tabular}{|c|c|c|c|}
\hline Sampling time & Blood concentration (ng/ml) & Number of patients & Percentage of patients \\
\hline \multirow[t]{5}{*}{ Minimum (trough) concentration (C0) } & $<150$ & 9 & $11.25 \%$ \\
\hline & Range $100-150$ & & \\
\hline & $>200$ & 5 & $6.25 \%$ \\
\hline & Range $200-250$ & & \\
\hline & $150-200^{\mathrm{A}}$ & 66 & $82.5 \%$ \\
\hline \multirow[t]{5}{*}{ Maximum concentration after $2 \mathrm{~h}$ of drug intake (C2) } & $<700$ & 9 & $11.25 \%$ \\
\hline & Range $600-700$ & & \\
\hline & $>900$ & 5 & $6.25 \%$ \\
\hline & $900-1100$ & & \\
\hline & $700-900^{\mathrm{B}}$ & 66 & $82.5 \%$ \\
\hline
\end{tabular}

A: Therapeutic minimum concentration ( $\mathrm{C} 0$ ) of cyclosporine, B: Maximum Therapeutic concentration (C2) after $2 \mathrm{~h}$ of drug intake

Table 3: Lymphocyte counts in control subjects versus the patient using cyclosporine

\begin{tabular}{|c|c|c|c|c|c|}
\hline Parameter & Group & $\mathbf{N}$ & Mean & \pm SD & P-value \\
\hline \multirow[t]{2}{*}{ Lymphocytes count (e3/uL) } & All patients & 80 & 1.26 & 0.60 & $0.02066^{*}$ \\
\hline & Control & 40 & 1.98 & 0.66 & \\
\hline \multirow[t]{2}{*}{ Lymphocytes count $(\mathrm{e} 3 / \mathrm{uL})$} & Patients with therapeutic cyclosporine concentrations ( $\mathrm{C} 0$ and $\mathrm{C} 2$ ) & 66 & 1.34 & 0.57 & $0.03189^{*}$ \\
\hline & Control & 40 & 1.98 & 0.66 & \\
\hline
\end{tabular}

*Significant difference

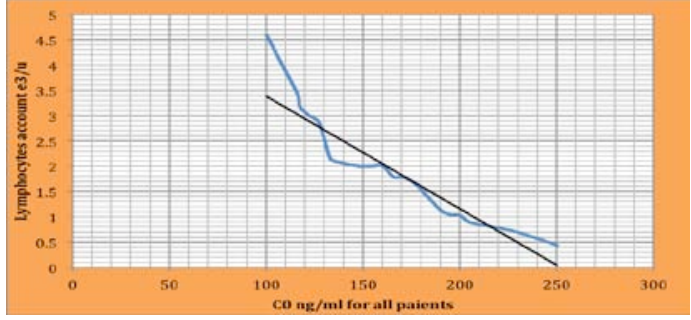

Fig. 3A: Correlation between lymphocyte count and $\mathrm{CO}$ for all patients

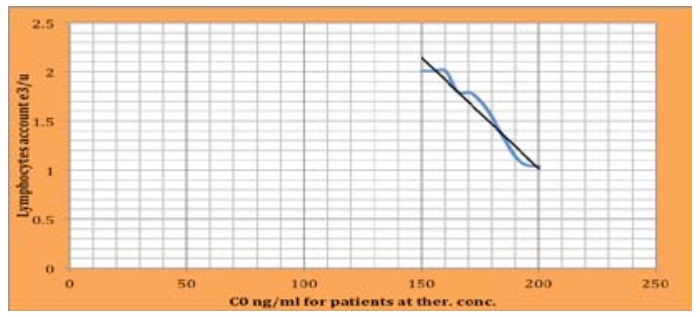

Fig. 3B: Correlation between lymphocyte count and CO for patients with therapeutic blood concentrations of cyclosporine

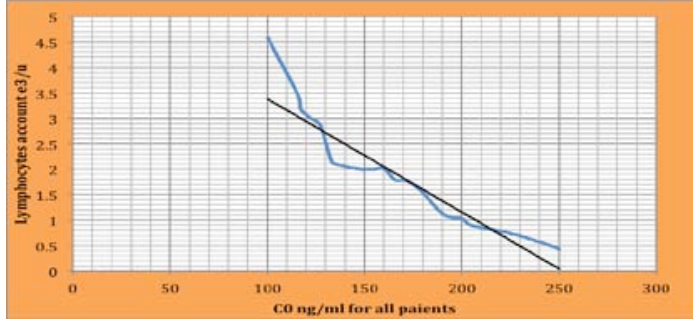

Fig. 4A: Correlation between lymphocyte count and C0 for all patients

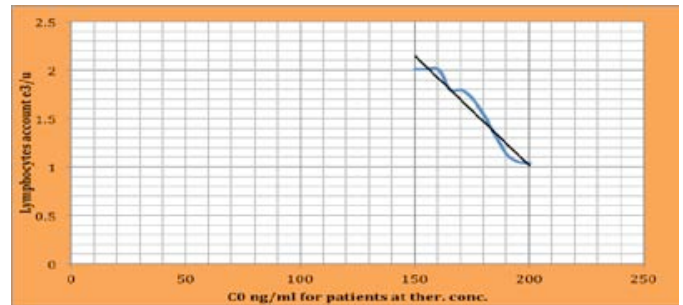

Fig. 4B: Correlation between lymphocyte count and $\mathrm{CO}$ for patients with therapeutic blood concentrations of cyclosporine 


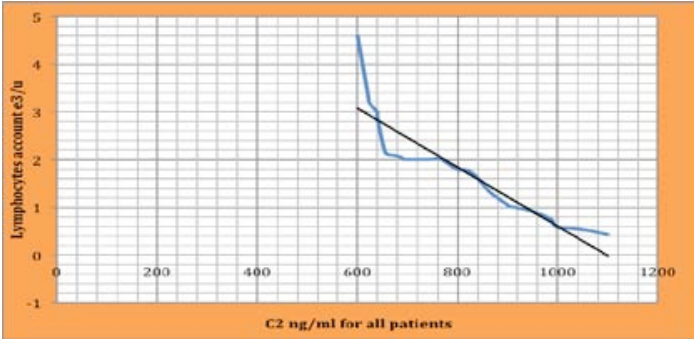

Fig. 5A: Correlation between lymphocyte count and C2 for all patients

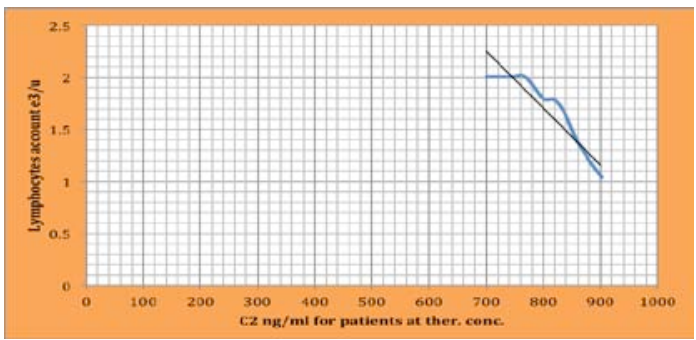

Fig. 5B: Correlation between lymphocyte count and C2 for patients with therapeutic blood concentrations of cyclosporine

\begin{abstract}
Lymphocytes percentage versus blood levels of cyclosporine for the patients versus the control subjects
\end{abstract}

Table 4 shows that the mean total lymphocyte percentage decreased significantly in all patients compared to control subjects $(19.92 \pm 13.77$ vs. $28.88 \pm 10.22 \mathrm{e}^{3} / \mathrm{uL}$ ). A similar trend was found for lymphocyte percentage of patients with cyclosporine blood levels within the therapeutic range (66 patients) compared to control subjects $(18.98 \pm 10.93$ vs. $28.88 \pm 10.22)$. The correlation between lymphocyte percentage and $\mathrm{C} 0$ for all patients and for patients with cyclosporine blood concentrations within the therapeutic range is introduced in fig. $6 \mathrm{~A}$ and $6 \mathrm{~B}$, respectively. In both cases good negative correlation observed with $r=0.93295$ (fig. 6A), and $r=0.97361$ (fig. 6B).

The correlation between lymphocyte percentage and C2 for all patients and for patients with cyclosporine blood concentrations within the therapeutic range is introduced in fig. 7A and 7B, respectively. In both cases good negative correlation observed with $r=0.91052$ (fig. 7A), and $r=0.95185$ (fig. 7B).

Percentage of CD4 T-helper cell at $\mathrm{CO}$ for the patients versus the control subjects

Table 5 demonstrates that CD4 T-helper cell percentage at CO decreased significantly in all patients compared to control subjects $(24.33 \pm 10.31$ vs. $35.83 \pm 9.11)$. Similar trend was found for CD4 Thelper cell percentage at $\mathrm{C} 0$ in the patients with cyclosporine blood concentrations within the therapeutic range (66 patients) compared to the control subjects $(25.50 \pm 2.44$ vs. $35.83 \pm 9.11)$.

Table 4: Lymphocyte percentage in the control subjects versus the patients using cyclosporine

\begin{tabular}{|c|c|c|c|c|c|}
\hline Parameter & Group & $\mathbf{N}$ & Mean & \pm SD & P-value \\
\hline \multirow[t]{2}{*}{ Lymphocytes \% } & All patients & 80 & 19.92 & 13.77 & $0.03336^{*}$ \\
\hline & Control & 40 & 28.88 & 10.22 & \\
\hline \multirow[t]{2}{*}{ Lymphocytes \% } & Patients with therapeutic cyclosporine concentrations ( $\mathrm{C} 0$ and $\mathrm{C} 2$ ) & 66 & 18.98 & 10.93 & $0.00732 *$ \\
\hline & Control & 40 & 28.88 & 10.22 & \\
\hline
\end{tabular}

*Significant difference

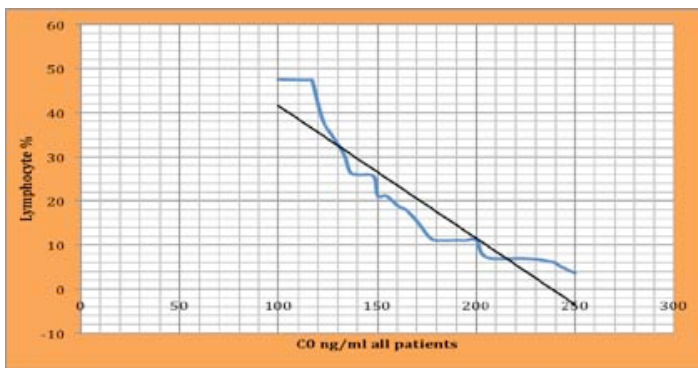

Fig. 6A: Correlation between lymphocyte percentage and $\mathrm{CO}$ for all patients

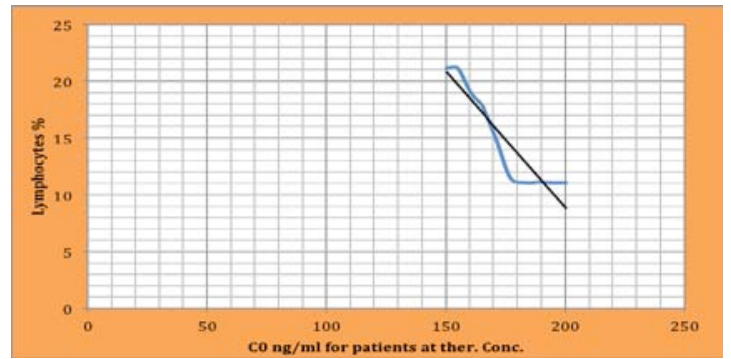

Fig. 6B: Correlation between lymphocyte percentage and C0 for patients with therapeutic blood concentrations of cyclosporine

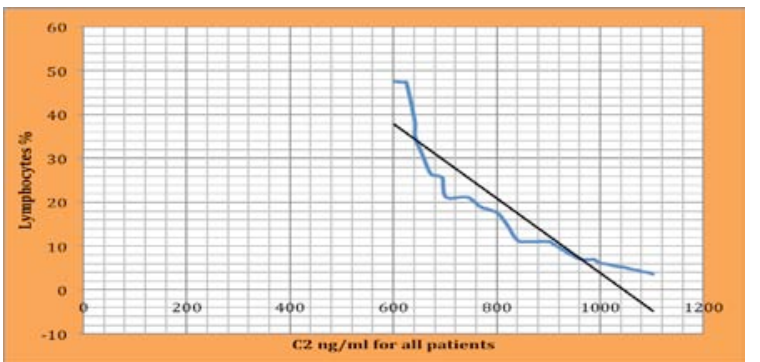

Fig. 7A: Correlation between lymphocyte percentage and C2 for all patients

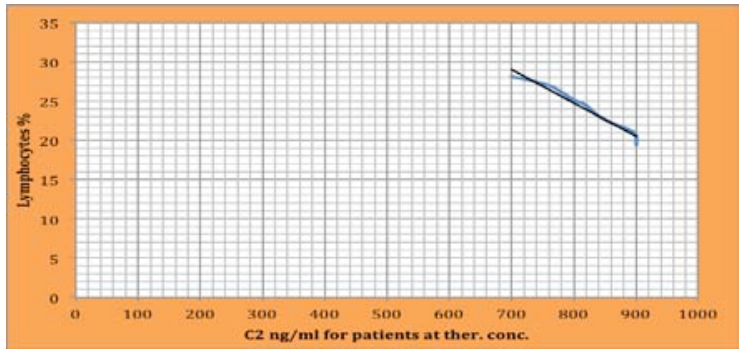

Fig. 7B: Correlation between lymphocyte percentage and C2 for patients with therapeutic blood concentrations of cyclosporine 
Table 5: Percentage of CD4 T-helper cell at $\mathrm{CO}$ for the control subjects versus the patients using cyclosporine

\begin{tabular}{|c|c|c|c|c|c|}
\hline Parameter & Group & $\mathbf{N}$ & Mean & $\pm \mathbf{S D}$ & P-value \\
\hline \multirow[t]{2}{*}{ CD4 T-helper $\%$ at C0 } & All patients & 80 & 24.33 & 10.31 & $0.00122^{*}$ \\
\hline & Control & 40 & 35.83 & 9.11 & \\
\hline \multirow[t]{2}{*}{ CD4 T-helper $\%$ at C0 } & Patients With therapeutic cyclosporine concentrations & 66 & 25.50 & 2.44 & $0.01097 *$ \\
\hline & Control & 40 & 35.83 & 9.11 & \\
\hline
\end{tabular}

*Significant difference

Percentage of CD4 T-helper cell at $\mathrm{C} 2$ for the patients versus the control subjects

Table 6 denote that CD4 T-helper cell percentage at C2 decreased significantly in all the patients compared to control subjects (22.60 \pm 9.28 vs. $35.83 \pm 9.11$ ). A similar trend was found for CD4 Thelper cell percentage at C2 in patients with cyclosporine blood concentrations within the therapeutic range compared to the control subjects $(21.50 \pm 2.16$ vs. $35.83 \pm 9.11)$.

\begin{abstract}
Range of CD4 T-helper cell percentage at $\mathrm{CO}$ for all patients
Table 7 show that the range of CD4 T-helper cell percentage at $\mathrm{C} 0$ for patients with cyclosporine blood levels above the therapeutic concentrations was 21.65-23.43 with mean \pm SD $(22.67 \pm 0.81)$; for patients with cyclosporine blood levels within the therapeutic concentrations, the range was 23.70-29.00 with mean \pm SD (25.52 \pm 2.44$)$; and for patients with cyclosporine blood levels below the therapeutic concentrations, the range was 29.80-34.60 with mean \pm SD (31.72 \pm 1.60$)$.
\end{abstract}

Table 6: Percentage of CD4 T-helper cell at C2 for the control subjects versus the patients using cyclosporine

\begin{tabular}{|c|c|c|c|c|c|}
\hline Parameter & Group & $\mathbf{N}$ & Mean & \pm SD & P-value \\
\hline CD4 T-helper \% at C2 & All patients & 80 & 22.60 & 9.28 & $0.00013^{*}$ \\
\hline & Control & 40 & 35.83 & 9.11 & \\
\hline CD4 T-helper \% at C2 & Patients with therapeutic cyclosporine concentrations & $\begin{array}{l}66 \\
40\end{array}$ & $\begin{array}{l}21.50 \\
3583\end{array}$ & 2.16 & $0.003432 *$ \\
\hline
\end{tabular}

*Significant difference

Table 7: Range of CD4 T-helper cell percentage at $\mathrm{CO}$ for all patients, total number of patients=80

\begin{tabular}{|c|c|c|c|}
\hline Patients (total 80) & Range of CD4\% at C0 & Mean & \pm SD \\
\hline Patients with cyclosporine blood col & $21.65-23.43$ & 22.67 & 0.81 \\
\hline Patients with cyclosporine blood concentrations within therapeutic range ( 66 patients) & 23.7-29.00 & 25.52 & 2.44 \\
\hline Patients with cyclosporine blood concentrations below therapeutic concentration ( 9 patients onl) & 29.8-34.60 & 31.72 & 1.60 \\
\hline
\end{tabular}

Since the percentage of CD4 T-helper cell in control subjects was 35.8 , thus a clear reduction in the percentage of CD4 T-helper cell occurred when $\mathrm{CO}$ were above and within therapeutic levels. However, when $\mathrm{C} 0$ were below the therapeutic levels, the reduction in the percentage of CD4 T-helper cell was not remarkable. This reflects the direct influence of $\mathrm{C} 0$ levels on reducing the percentage of CD4 T-helper cell and consequently the depression of immunity from kidney transplanted patients. The correlation between CD4 Thelper cell percentage and $\mathrm{C} 0$ for all patients is shown in fig. 8A. The correlation between CD4 T-helper cell percentage and C0 for patients with blood concentrations of cyclosporine within the therapeutic range is depicted in fig. 8B. In both situations, good negative correlations were found with $r=0.97928$ (fig. 8A) and $r=0.9379$ (fig. 8B).

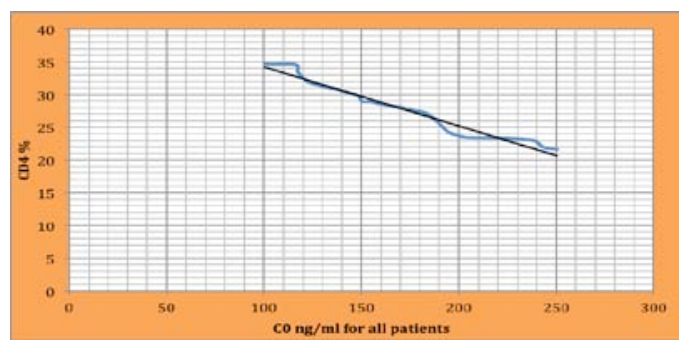

Fig. 8A: Correlation between CD4 T-helper cell percentage and CO for all patients

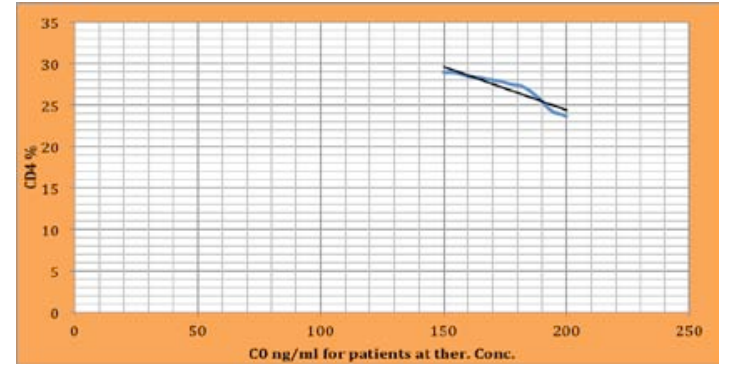

Fig. 8B: Correlation between CD4 T-helper cell percentage and $\mathrm{CO}$ for patients with therapeutic blood concentrations of cyclosporine

Range of CD4 T-helper cell percentage at $\mathrm{C} 2$ for all patients

Table 8 display that the CD4 T-helper cell percentage range at $\mathrm{C} 2$ for patients with cyclosporine blood levels above the therapeutic concentrations was $13.40-18.20$ with mean \pm SD $(16.08 \pm 1.96)$; for patients with cyclosporine blood levels within the therapeutic concentrations, the range were 18.50-22.23 with mean \pm SD (21.52 \pm 2.19$)$; and for patients with cyclosporine blood levels below the therapeutic concentrations, the range were 22.76-24.42 with mean \pm SD $(23.75 \pm 0.66)$.

Table 8: Range of CD4 T-helper cell percentage at $\mathrm{C} 2$ for all patients, $\mathrm{N}=80$ patients

\begin{tabular}{|c|c|c|c|}
\hline Patients & Range of CD4\% at C2 & Mean & \pm SD \\
\hline Patients with cyclosporine blood concentrations above therapeutic range ( 5 patients only) & $13.40-18.2$ & 16.08 & 1.96 \\
\hline Patients with cyclosporine blood concentrations within therapeutic range (66 patients) & $18.5-22.23$ & 21.52 & 2.19 \\
\hline Patients with cyclosporine blood concentrations below therapeutic concentratio & $22.76-24.42$ & 23.75 & 0.66 \\
\hline
\end{tabular}


Since the percentage of CD4 T-helper cell in control subjects was 35.80 , thus an apparent reduction in the CD4 T-helper cell occurred when C2 were above, within and below the therapeutic levels. However, the reduction in the percentage of CD4 T-cell was more remarkable when $\mathrm{C} 2$ were above and within the therapeutic levels. This reflects the direct impact of C2 levels on reducing the percentage of CD4 T-helper cell and consequently the depression of immunity for kidney transplanted patients. The correlation between CD4 T-helper cell percentage and C2 for all patients is shown in fig. 9A. The correlation between CD4 T-helper cell percentage and C2 for patients with blood concentrations of cyclosporine within the therapeutic range is illustrated in fig. 9B. In both cases, good negative correlations were found with $r=0.99606$ (fig. 9A) and $r=$ 0.98188 (fig. 9B)

\section{Range of CD4 T-helper cell percentage at $\mathrm{C} 2$ to $\mathrm{CO}$ for the patients}

Table 9 demonstrates that, for patients with cyclosporine blood levels above therapeutic concentrations; the minimum percentage of CD4 T-helper cell at C2 was 13.40, whereas the maximum percentage of CD4 T-helper cell at $\mathrm{C} 0$ was 20.23. For patients with cyclosporine blood levels within therapeutic concentrations; the minimum percentage of CD4 T-helper cell at $\mathrm{C} 2$ was 18.50 , whereas the maximum percentage of CD4 T-helper cell at C0 was 29.00. For patients with cyclosporine blood levels below therapeutic concentrations; the minimum percentage of CD4 T-helper cell at C2 was 23.40, whereas the maximum percentage of CD4 T-helper cell at C0 was 34.60.

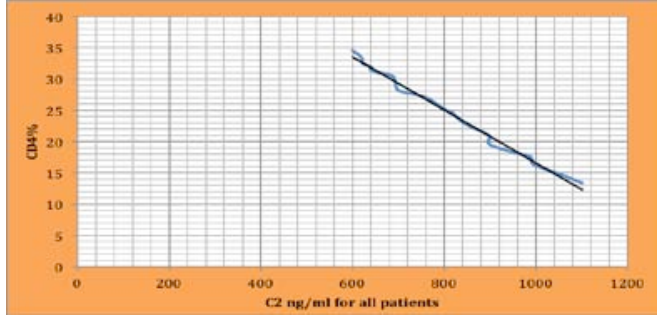

Fig. 9A: Correlation between CD4 T-helper cell percentage and C2 for all patients

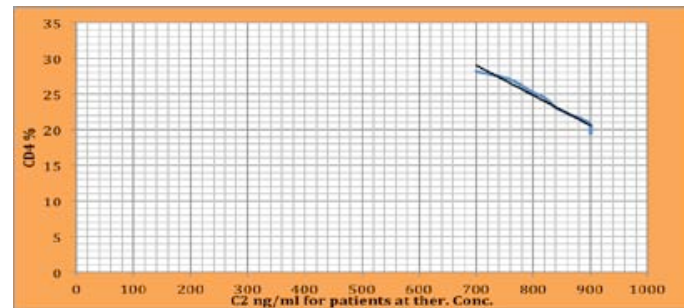

Fig. 9B: Correlation between CD4 T-helper cell percentage and C2 for patients with therapeutic blood concentrations of cyclosporine

Table 9: Range of CD4 T-helper cell percentages at $\mathrm{C} 2$ to $\mathrm{C} 0$ for patients with cyclosporine blood concentrations above, within and below therapeutic levels

\begin{tabular}{llc}
\hline Patients & $\begin{array}{l}\text { Range of CD4 T-helper cell percentage } \\
\text { at C2 to C0 }\end{array}$ & $\begin{array}{l}\text { Mean of } \\
\text { range }\end{array}$ \\
\hline $\begin{array}{l}\text { CD4 T-helper cell percentage for patients with cyclosporine blood levels above } \\
\text { therapeutic concentrations }\end{array}$ & $14.30-20.23$ \\
$\begin{array}{l}\text { CD4 T-helper cell percentage for patients with cyclosporine blood levels within } \\
\text { therapeutic concentrations }\end{array}$ & $18.50-29.00$ \\
$\begin{array}{l}\text { CD4 T-helper cell percentage for patients with cyclosporine blood levels below } \\
\text { therapeutic concentrations }\end{array}$ & $23.40-34.60$ \\
\hline
\end{tabular}

\section{DISCUSSION}

\section{Dosage of cyclosporine}

The maintenance dose of cyclosporine in renal transplanted patients is $5-10 \mathrm{mg} / \mathrm{kg} / \mathrm{d}$ [13] and therapeutic blood concentrations $\mathrm{C} 0$ range $150-200 \mathrm{ng} / \mathrm{ml}$, and C2 range $700-900 \mathrm{ng} / \mathrm{ml}$ [14].

In the present study, the distribution of the different cyclosporine doses; as $1-2 \mathrm{mg} / \mathrm{kg} / \mathrm{d}, 2.1-3 \mathrm{mg} / \mathrm{kg} / \mathrm{d}, 3.1-4 \mathrm{mg} / \mathrm{kg} / \mathrm{d}, 4.1-5$ $\mathrm{mg} / \mathrm{kg} / \mathrm{d}, \quad 5.1-6 \mathrm{mg} / \mathrm{kg} / \mathrm{d}, 6.1-7 \mathrm{mg} / \mathrm{kg} / \mathrm{d}, \quad 7.1-8 \mathrm{mg} / \mathrm{kg} / \mathrm{d}, 8.1-9$ $\mathrm{mg} / \mathrm{kg} / \mathrm{d}$ and $9.1-10 \mathrm{mg} / \mathrm{kg} / \mathrm{d}$ were; 1 (1.25\%), 3 (3.75\%), 5 (6.25\%), 11 (13.75\%), 31 (38.75\%), 9 (11.25\%), 7 (8.75\%), 8 $(10 \%)$ and $5(6.25 \%)$, respectively. The range of doses that produce cyclosporine therapeutic range was $4.1-9 \mathrm{mg} / \mathrm{kg} / \mathrm{d}$. Further studies on Iraqi kidney transplant patients are needed to support the present result.

\section{Blood levels of cyclosporine}

Dose adjustment of medication is accomplished according to the blood levels. A high level can be harmful to the transplanted kidney, and a low level may lead to rejection [15]. Patient's cyclosporine levels should often be measured for the rest of their life. In Iraq, cyclosporine levels are measured in Baghdad Teaching Hospital/ TDM unit in periods depending on the time of transplantation.

The current findings showed that the number of patients with a therapeutic range of cyclosporine ( $\mathrm{C} 0=150-200 \mathrm{ng} / \mathrm{ml}$, and $\mathrm{C} 2=700$ $900 \mathrm{ng} / \mathrm{ml}$ ) was $66(82.5 \%)$ who received dose range of $4.1-9$ $\mathrm{mg} / \mathrm{kg} / \mathrm{d}$. The number of patients with levels above therapeutic range $(205-250 \mathrm{ng} / \mathrm{ml}$ for $\mathrm{C} 0$ and $955-1100 \mathrm{ng} / \mathrm{ml}$ for C2) was 5 $(6.25 \%)$ who received dose $9.1-10 \mathrm{mg} / \mathrm{kg} / \mathrm{d}$ of cyclosporine.
Whereas, the number of patients with levels under the therapeutic range $(100-148 \mathrm{ng} / \mathrm{ml}$ for $\mathrm{C} 0$ and $600-693$ for C2) was $9(11.25 \%)$ who received doses less than $4 \mathrm{mg} / \mathrm{kg} / \mathrm{d}$.

\section{Cyclosporine dose and concentration relationship}

The concept of the therapeutic range in population-based statistical approaches, suggesting that most patients who achieve a desired therapeutic response commonly occur at specific target concentrations. Significant variability in cyclosporine pharmacokinetics, the narrow therapeutic index, the dangerous adverse effects justify the use of TDM for cyclosporine [16].

Although, there is a significant variability in the pharmacokinetics of cyclosporine, the present finding showed good correlation between doses and blood concentrations at C0 and C2 with $\mathrm{r}=0.901$ and $\mathrm{r}=0.914$, respectively.

\section{Lymphocytes and CD4 T-helper cell}

Cyclosporine causes inhibition of IL-2 and other cytokines production throughout a complex formation with cyclophilin that inhibits calcineurin leading to diminishing of T-cell activation [17]. Cyclosporine cause calcineurin inhibition in $\mathrm{T}$ cells that block the dephosphorylation and translocation of NFATc then inhibition of cytokine production from memory $\mathrm{CD} 4+\mathrm{T}$ cells occur as a consequence, the differentiation of naive $\mathrm{CD} 4+\mathrm{T}$ cells into cytokineproducing memory CD4+T cells is prevented [18].

One measurable effect of low dose of cyclosporine, a significant reduction in absolute numbers of CD4+T cell count at weeks 2 and 4 is observed and this is related to the inhibition of IL-2-induced T cell proliferation ability of cyclosporine [19]. 
Lymphocytes count and blood levels ( $\mathrm{C} 0$ and $\mathrm{C} 2$ ) of cyclosporine for the patients versus the control subjects

In this study, there was a significant reduction in mean total lymphocyte count in all patients (80 patients) compared to the control subjects (40 subjects). Besides, a significant reduction in total lymphocyte count was recorded in the patients (66 patients) with cyclosporine blood levels within the therapeutic range of $\mathrm{CO}$ and C2 compared to the control subjects. The present investigation also demonstrated a good negative correlation between lymphocyte count and $\mathrm{C} 0$ for all patients with $\mathrm{r}=0.932$ and for patients with $\mathrm{C} 0$ within the therapeutic range with $r=0.973$. Moreover, good negative correlation was observed between the lymphocyte count and C2 for all patients with $\mathrm{r}=0.904$ and for patients with C2 within the therapeutic range with $r=0.939$. This reduction in the total lymphocyte count is due to the reduction in CD4 T-helper cell count.

\section{Percentage of CD4 T-helper cell at $\mathrm{CO}$ for the patients versus the} control subjects

This study exhibited a significant reduction in CD4 T-helper cell percentage at $\mathrm{C} 0$ in all patients (80 patients) compared to the control subjects (40 subjects). Also, significant reduction in CD4 T-helper cell percentage at $\mathrm{C} 0$ in the patients with cyclosporine blood levels within the therapeutic range (66 patients) compared to the control subjects. This is due to inhibition of differentiation of naive CD4 T cells into cytokine-producing memory CD4 Thelper cell by cyclosporine.

\section{Percentage of CD4 T-helper cell at $\mathrm{C} 2$ for the patients versus the control subjects}

The current investigation elucidated significant reduction in CD4 Thelper cell percentage at $\mathrm{C} 2$ in all patients (80 patients) compared to the control subjects ( 40 subjects). In addition, a significant reduction in CD4 T-helper cell percentage at $\mathrm{C} 2$ in the patients with cyclosporine blood levels within the therapeutic range (66 patients) compared to the control subjects. This is due to inhibition of differentiation of naïve $\mathrm{CD} 4+\mathrm{T}$ cells into cytokine-producing memory CD4 $+\mathrm{T}$ cells by cyclosporine.

\section{Range of CD4 T-helper cell percentage at C0 for all patients}

In this study, the range of CD4 T-helper cell percentage at $\mathrm{C} 0$ for the patients with cyclosporine blood levels above the therapeutic concentrations was $21.65-23.43$ with mean \pm SD $(22.67 \pm 0.81)$; for patients with cyclosporine blood levels within the therapeutic concentrations, the range was $23.7-29$ with mean \pm SD $(25.52 \pm 2.44)$; and for patients with cyclosporine blood levels below the therapeutic concentrations, the range was 29.8-34.6 with mean \pm SD (31.72 \pm 1.60$)$. Since the percentage of CD4 T-helper cell in control subjects was 35.8 , thus an apparent diminishing in the percentage of CD4 T-helper cell took place when $\mathrm{C} 0$ were above and within therapeutic levels. However, when $\mathrm{C} 0$ were below the therapeutic levels, the decline in the percentage of CD4 T-helper cell was not noticeable. This indicates the direct effect of $\mathrm{C} 0$ levels on diminishing the percentage of CD4 T-helper cell and consequently decreasing the immunity on kidney transplant patients.

The present investigation demonstrated a good negative correlation between CD4 T-helper cell percentage and $\mathrm{C} 0$ for all patients with $r=0.97928$, and the good negative correlation between CD4 T-helper cell percentage and $\mathrm{C} 0$ for the patients with blood concentrations of cyclosporine within the therapeutic range with $r=0.9379$.

\section{Range of CD4 T-helper cell percentage at C2 for all patients}

In this study, the range of CD4 T-helper cell percentage at $\mathrm{C} 2$ for the patients with cyclosporine blood levels above the therapeutic concentrations was 13.4-18.2 with mean \pm SD (16.08 \pm 1.96$)$; for patients with cyclosporine blood levels within the therapeutic concentrations, the range was 18.5-22.23 with mean \pm SD (21.52 \pm 2.19$)$; and for patients with cyclosporine blood levels below the therapeutic concentrations, the range was 22.76-24.42 with mean \pm SD $(23.75 \pm 0.66)$.

Since the percentage of CD4 T-helper cell in control subjects was 35.8, thus a clear reduction in the CD4 T-helper cell occurred when C2 were above, within and below the therapeutic levels. However, the reduction in the percentage of CD4 T-cell was more apparent when $\mathrm{C} 2$ were above and within the therapeutic levels. This mirror the direct impact of $\mathrm{C} 2$ levels on decreasing the percentage of CD4 Thelper cell and consequently leads to decline in the immunity of kidney transplanted patients.

The current study display the good negative correlation between CD4 T-helper cell percentage and C2 for all patients with $\mathrm{r}=0.99606$, and the good negative correlation between CD4 T-helper cell percentage and $\mathrm{CO}$ for the patients with blood concentrations of cyclosporine within the therapeutic range with $\mathrm{r}=0.98188$.

\section{Range of CD4 T-helper cell percentage at $\mathrm{C} 2$ to $\mathrm{CO}$ for the patients}

The present instigation manifest that the patients with cyclosporine blood levels above therapeutic concentrations; the minimum percentage of CD4 T-helper cell at C2 was 13.40, whereas the maximum percentage of CD4 T-helper cell at C0 was 20.23. For patients with cyclosporine blood levels within therapeutic concentrations; the minimum percentage of CD4 T-helper cell at $\mathrm{C} 2$ was 18.50, whereas the maximum percentage of CD4 T-helper cell at C0 was 29.00. For patients with cyclosporine blood levels below therapeutic concentrations; the minimum percentage of CD4 Thelper cell at C2 was 23.40 , whereas the maximum percentage of CD4 T-helper cell at C0 was 34.60.

From these results, measurement of CD4 T-helper cell percentage could be used as an alternative marker to TDM for dosing cyclosporine. According to this approach, the monitoring is based on measuring CD4 T-helper cell percentage after $12 \mathrm{~h}$ of cyclosporine dose administration (trough cyclosporine blood level $\mathrm{C} 0$ ) and the range of CD4 T-helper cell percentages should be 23.7-29.00\%. The second measurement of CD4 T-helper cell percentage should be after $2 \mathrm{~h}$ of cyclosporine dosage administration (maximum or peak cyclosporine blood level C2) and the range should be 18.5-22.23\%. Hence, the dose administered to the patient should be adjusted to produce the above-mentioned ranges of CD4 T-helper cell percentage, then this dose can be considered as the optimal dose of cyclosporine which should be maintained to the patient; since this dose indicate that the patient is maintained within the therapeutic blood concentration ranges $\mathrm{C} 0$ and $\mathrm{C} 2$ of cyclosporine. Accordingly, measurement of CD4 T-helper cell percentage can be considered as a promising novel alternative/surrogate approach for cyclosporine dosing, since monitoring CD4 T-helper cell percentage is the direct, simple, fast and affordable approach.

\section{Limitation of the study}

1. The possibility of Cyclosporine dosage change in stable patients.

2. Period of the study should take longer to involve larger number of patients

3. Using the new, simple and rapid method for CD4 T-helper cells counting method.

\section{CONCLUSION}

For Iraqi kidney transplant patients using oral cyclosporine twice daily, it appeared that there is good negative (reciprocal) correlation between cyclosporine blood levels $(\mathrm{C} 0=$ trough or minimum level after $12 \mathrm{~h}$ of drug administration, and C2 = maximum level after $2 \mathrm{~h}$ of drug intake) and the percentage of CD4 T-helper cell. Since the latter parameter is a direct marker which reflects cyclosporine safety and efficacy, besides, measuring the percentage of CD4 T-helper cell is affordable, simple and fast. Thus, it can be concluded from the current study that the percentage of CD4 T-helper cell may be used as a novel promising alternative or surrogate marker for optimum cyclosporine dosing. Moreover, cyclosporine dose range of $4.1-9 \mathrm{mg} / \mathrm{kg} / \mathrm{d}$ yields therapeutic $\mathrm{C} 0$ and $\mathrm{C} 2$ in Iraqi kidney transplant patients.

\section{CONFLICT OF INTERESTS}

Declared none

\section{REFERENCES}

1. Carol Mattson Porth. Essentials of Pathophysiology: Concepts of Altered Health State. $3^{\text {rd }}$ ed. Lippincott Williams and Wilkins; 2011. 
2. Bueno V, Pestana JOM. The role of CD8+T cells during allograft rejection. Braz J Med Biol Res 2002;35:1247-58.

3. Kissinger P, Chan-Sik Park, Moon Kim, Polly Matzinger, Colin C Thymic cortical epithelium induces self-tolerance. Eur J Immunol 2005;35:709-17.

4. Scott G, Stuart LaForge, Viresh P, Christina M, M Carrie, Jerome A. T-lymphocytes cells express either the CD4 or the CD8 surface glycoprotein but not both. Am Soc Hematol 2002;99:1.

5. Kyle Woodward, Esma Yolcu, Hong Zhao, Laura Bandura-Morgan, Nadir Askenasy, Haval Shirwan. Pancreatic islets engineered with sa-fas 1 protein establish robust localized tolerance by inducing regulatory t cells in mice. J Immunol 2011:187:5901-9.

6. Robert O Bonow, Douglas L Mann, Douglas P Zipes, P Zipes, Peter Libby. Heart disease: a textbook of cardiovascular medicine. Peter Libby Elsevier Health Sci 2011;37:989-10.

7. Kirsten Geneugelijk, Kirsten Anne Thus, Eric Spierings. Predicting alloreactivity in transplantation. J Immunol Res 2014;12. Doi.org/10.1155/2014/159479.

8. Janeway CA Jr, Travers P, Walport M. The Immune System in Health and Disease. 5th ed. Garland Science 2001.

9. Sindhi R, LaVia MF, Paulling E. Stimulated response of peripheral lymphocytes may distinguish cyclosporine effect in renal transplant recipients receiving a cyclosporine+ rapamycin regimen. Transplant 2000;69:432-6.

10. Miroux C1, Moralès $\mathrm{O}$, Carpentier A, Dharancy S, Conti F, Boleslowski $\mathrm{E}$, et al. Inhibitory effects of cyclosporine on human regulatory $\mathrm{T}$ cells in vitro. Transplant Proc 2009;41:3371-4.

11. Hulgan T1, Donahue JP, Smeaton L, Pu M, Wang H, Lederman $\mathrm{MM}$, et al. Oral cyclosporine a inhibits CD4 T cell P-glycoprotein activity in HIV-infected adults initiating treatment with nucleoside reverse transcriptase inhibitors. Eur J Clin Pharmacol 2009;65:1081-8.
12. Hoerning A1, Köhler S, Jun C, Lu J, Fu J, Tebbe B. Cyclosporine but not Everolimus inhibits chemotaxine receptor expression on CD4+T cell subsets circulating in the peripheral blood of renal transplant recipients. Clin Exp Immunol 2012;168:251-9.

13. Robert $\mathrm{S}$ Gaston. Maintenance immunosuppression in the renal transplant recipient. Am J Kidney Dis 2001;38:25.

14. Z Tolou-Ghamari, A Palizban, M Gharavi. Cyclosporine trough concentration and its relationship. Medical Sciences and Health Services, J Nephr 2002;1:1-6.

15. Michael Brown Carl Wittwera. Flow cytometry: principles and clinical applications in hematology. Clin Chem 2000;46:1221-9.

16. Qume Drive, San Jose. Introduction to flow cytometry: a learning guide. Manual Part Number: 11-11032-01. 2350 CA 95131, USA; 2000.

17. Robert R Rich, Thomas A Fleisher, William T Shearer. Clinical Immunology, Principles and Practice. Clinical Immunology. $4^{\text {th }}$ ed. Health Sciences; 2012. p. 396.

18. Kenshiro Tsuda, Keiichi Yamanaka, Tomoko Akeda, Hiroshi Kitagawa, Tomoko Akeda, Masanao Naka, et al. Calcineurin inhibitors suppress cytokine production from memory $\mathrm{t}$ cells and differentiation of naïve $t$ cells into cytokine-producing mature t cells. PLoS One 2012;7:e31465.

19. Martin Markowitz, Florin Vaida, C Bradley Hare, Daniel Boden, Hiroshi Mohri, Frederick M Hecht, et al. The virologic and immunologic effects of cyclosporine as an adjunct to antiretroviral therapy in patients treated during acute and early HIV-1 infection. J Infect Dis 2011;201:1298-302.

\section{How to cite this article}

- Jaafar Jaber Ibraheem AL-Tamimi, Qutaiba Ahmed Ibrahim ALkhames Aga, Hassan Mohammed Abass. CD4 t-helper cell count is an alternative promising marker for dosing cyclosporine in kidney transplant patient. Int J Pharm Pharm Sci 2016;8(9):85-92. 